\title{
Regulation of cell signalling by vitamin $E$
}

\author{
Gerald Rimbach ${ }^{1 *}$, Anne Marie Minihane ${ }^{1}$, Jonathan Majewicz ${ }^{1}$, Alexandra Fischer $^{2}$, \\ Josef Pallauf ${ }^{2}$, FabioVirgli $^{3}$ and Peter D. Weinberg ${ }^{4}$ \\ ${ }^{1}$ Hugh Sinclair Human Nutrition Unit, School of Food Biosciences, University of Reading, Reading RG6 6AP, UK \\ ${ }^{2}$ Institute of Animal Nutrition and Nutrition Physiology, Justus-Liebig-University, Giessen, Germany \\ ${ }^{3}$ National Institute of Food and Nutrition Research, Rome, Italy \\ ${ }^{4}$ School of Animal and Microbial Sciences, University of Reading, Reading RG6 6AJ, UK
}

\begin{abstract}
Vitamin E, the most important lipid-soluble antioxidant, was discovered at the University of California at Berkeley in 1922. Since its discovery, studies of the constituent tocopherols and tocotrienols have focused mainly on their antioxidant properties. In 1991 Angelo Azzi's group (Boscoboinik et al. 1991a,b) first described non-antioxidant cell signalling functions for $\alpha$-tocopherol, demonstrating that vitamin $\mathrm{E}$ regulates protein kinase $\mathrm{C}$ activity in smooth muscle cells. At the transcriptional level, $\alpha$-tocopherol modulates the expression of the hepatic $\alpha$-tocopherol transfer protein, as well as the expression of liver collagen alpha1 gene, collagenase gene and $\alpha$-tropomyosin gene. Recently, a tocopherol-dependent transcription factor (tocopherolassociated protein) has been discovered. In cultured cells it has been demonstrated that vitamin $\mathrm{E}$ inhibits inflammation, cell adhesion, platelet aggregation and smooth muscle cell proliferation. Recent advances in molecular biology and genomic techniques have led to the discovery of novel vitamin E-sensitive genes and signal transduction pathways.
\end{abstract}

\section{Résumé}

La vitamine E, l'antioxydant liposoluble le plus important, fut découverte à l'Université de Californie à Berkeley en 1922. Depuis sa découverte, les études sur les tocophérols et les tocotrienols que constitue cette vitamine, ont été centrées pour la plupart sur leurs propriétés antioxydantes. En 1991, le groupe de Angelo Azzi (Boscoboinik et al. 1991a,b) fut le premier à décrire les fonctions autres que les antioxydantes et de transmission de signaux de l' $\alpha$-tocophérol, en démontrant la régulation par la vitamine $\mathrm{E}$ de l'activité de la protéine kinase $\mathrm{C}$ dans les cellules de muscle lisse. Au niveau de la transcription, l' $\alpha$-tocophérol module l'expression de la protéine de transfert hépatique de l' $\alpha$-tocophérol, ainsi que l'expression du gène alpha1 du collagène du foie, du gène de la collagénase et du gène de l' $\alpha$-tropomyosine. Récemment, un facteur de transcription dépendant du tocophérol (la protéine associée au tocophérol) a été découvert. Il a été démontré sur des cellules cultivées que la vitamine $\mathrm{E}$ inhibe l'inflammation, l'adhésion cellulaire, l'agrégation des plaquettes et la prolifération des cellules de muscle lisse. Les avancées récentes de la biologie moléculaire et des techniques génomiques ont conduit à la découverte de nouveaux gènes et des mécanismes de transduction des signaux sensibles à la vitamine $\mathrm{E}$.

Antioxidants: Vitamin E: Gene expression: Cell signalling: Cardiovascular disease

\section{Chemistry and antioxidant properties of vitamin $\mathbf{E}$}

Vitamin E consists of a mixture of tocopherols and tocotrienols that are synthesised by plants from homogenestic acid. All are derivatives of 6-chromanol with an aliphatic side-chain. The four tocopherol homologues $(\alpha-, \beta-, \gamma$ - and $\delta$-) have a fully saturated $\mathrm{C}_{16}$ phytol side-chain, whereas tocotrienols have a similar isoprenoid chain containing three double bonds. Individual tocopherols are named according to the position and number of the methyl groups on the

\footnotetext{
Abbreviations: COX, cyclo-oxygenase; ICAM-1, intracellular adhesion molecule-1; MCP-1, monocyte chemoattractant protein-1; NF- $\kappa$ B, nuclear factor kappa B; PKC, protein kinase C; PUFA, polyunsaturated fatty acids; $\alpha$-TTP, $\alpha$-tocopherol transfer protein; VCAM-1, vascular cell adhesion molecule-1. *Corresponding author: Dr Gerald Rimbach, fax + 44118931 0080, email g.h.rimbach@reading.ac.uk
} 


\begin{tabular}{cccc} 
& $\mathrm{R}_{1}$ & $\mathrm{R}_{2}$ & $\mathrm{R}_{3}$ \\
\hline$\alpha$ & $\mathrm{CH}_{3}$ & $\mathrm{CH}_{3}$ & $\mathrm{CH}_{3}$ \\
$\beta$ & $\mathrm{CH}_{3}$ & $\mathrm{H}$ & $\mathrm{CH}_{3}$ \\
$\gamma$ & $\mathrm{H}$ & $\mathrm{CH}_{3}$ & $\mathrm{CH}_{3}$ \\
$\delta$ & $\mathrm{H}$ & $\mathrm{H}$ & $\mathrm{CH}_{3}$
\end{tabular}

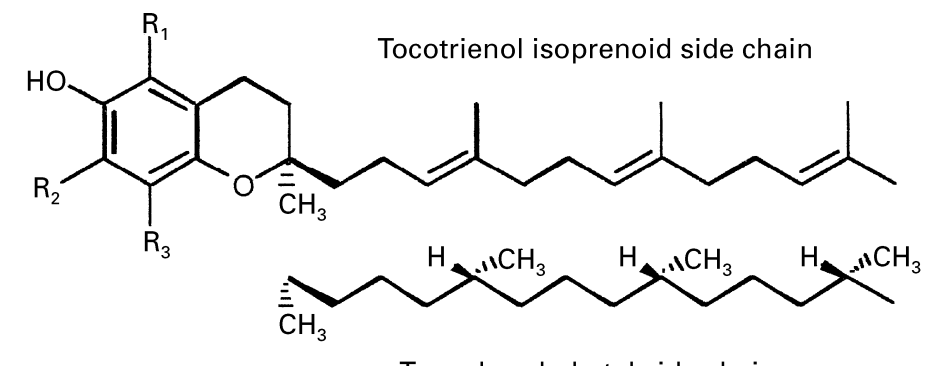

Tocopherol phytyl side chain

Fig. 1. Molecular structure of vitamin E stereoisomers.

phenol ring, with the $\alpha-, \beta-, \gamma$ - and $\delta$-tocopherols containing three, two, two and one methyl groups respectively (Fig. 1). These structural differences determine biological activity, $\alpha$-homologues being the most biologically active.

The majority of the functionality of vitamin $\mathrm{E}$ is through its role as an antioxidant, maintaining the structural integrity of virtually all cells in the body. Its antioxidant function is mediated through the reduction of free radicals, thus protecting the body against the deleterious effects of such highly-reactive oxygen and nitrogen species, which have been implicated in ageing and a number of chronic diseases such as atherosclerosis, cancers and rheumatoid arthritis (Halliwell, 1996; Parthasarathy et al. 1999; Malins et al. 2001). The reactive oxygen species which include $\mathrm{H}_{2} \mathrm{O}_{2}$, the superoxide radical $\left(\mathrm{O}_{2}{ }^{-}\right)$, and the highly-reactive hydroxyl radical $\left(\mathrm{OH}^{*}\right)$, are by-products of normal aerobic metabolism formed during the respiratory and phagocytic processes, and during microsomal cytochrome P-450 metabolism. The reactive nitrogen species include $\mathrm{NO}^{*}$ and peroxynitrite, formed by the reaction of $\mathrm{NO}^{-}$and $\mathrm{O}_{2}{ }^{-}$.

The polyunsaturated fatty acids (PUFA) of biological membranes are particularly susceptible to free radical attack due to their high degree of unsaturation. In brief, the process is initiated by a free radical such as $\mathrm{OH}^{-}$, which extracts $\mathrm{H}$ from PUFA resulting in a $\mathrm{PUFA}^{\circ}$ radical. Following molecular rearrangement to form a conjugated diene the molecule is susceptible to attack by $\mathrm{O}_{2}$ resulting in a peroxyl radical (PUFAOO'). PUFAOO' are capable of extracting $\mathrm{H}$ from adjacent PUFA, thus propagating a chain reaction. Such auto-oxidation continues, severely affecting the functionality of the tissue, unless the free radicals are scavenged. Due to its abundance, lipid solubility and efficacy with respect to radical quenching, vitamin $\mathrm{E}$ is considered to be the most important antioxidant in cell membranes (Ingold et al. 1987; Halliwell, 1996; BrigeliusFlohe \& Traber, 1999).

The antioxidant property of vitamin $\mathrm{E}$ is exerted through the phenolic hydroxyl group, which readily donates its $\mathrm{H}$ to the PUFAOO ${ }^{*}$ radical, resulting in the formation of a stable lipid species. In donating the $\mathrm{H}$, vitamin $\mathrm{E}$ becomes a relatively unreactive free radical, as the unpaired electron becomes delocalised into the aromatic ring. The efficiency of this protection depends on two factors: first the mobility of the molecule in membranes, which is determined by the aliphatic tail; second the number of methyl species on the chromanol ring, with each methyl group conferring additional antioxidant capacity. In addition, the proximity of the methyl species to the hydroxyl group is an important factor. Thus, $\alpha$-homologues, which have the greatest number of methyl species, and in which these methyl groups flank the hydroxyl group, are thought to be more effective than the other homologues.

$\alpha$-Tocotrienol has been shown to be more effective in protecting against lipid peroxidation than $\alpha$-tocopherol (Serbinova et al. 1991; Suzuki et al. 1993). A reason suggested for this greater effectiveness is the nature of the aliphatic tail. The isoprenoid chain of $\alpha$-tocotrienol has a stronger disordering effect on membranes than $\alpha$-tocopherol. This property leads to a greater mobility and more uniform distribution within the membrane. NMR studies have also shown that the chromanol ring of $\alpha$-tocotrienol is situated closer to the membrane surface. These factors contribute to a greater ability of tocotrienols to interact with radicals and allow for quicker recycling of the molecule to its active reduced form (Serbinova et al. 1991; Suzuki et al. 1993).

Although vitamin $\mathrm{E}$ plays a unique role within membranes it does not function in isolation. Protecting the cell from the deleterious effect of oxidative stress involves an array of other membrane and water-soluble antioxidants and antioxidant enzymes, which together form the 'antioxidant defence system' (Fig. 2). In this multifactorial system the cytosolic metalloenzymes serve in the prevention of free radical formation. Superoxide dismutase serves to convert $\mathrm{O}_{2}{ }^{--}$to $\mathrm{H}_{2} \mathrm{O}_{2}$, whereas glutathione peroxidase and catalase further reduce $\mathrm{H}_{2} \mathrm{O}_{2}$, thus preventing the formation of the highly-reactive $\mathrm{OH}^{\circ}$. The water-soluble antioxidants can act as cofactors for the antioxidant enzymes, can serve as independent antioxidants or can function in the recycling of vitamin E (Packer et al. 2001). Vitamin E exists in membranes at a concentration of one molecule per 2000-3000 phospholipids and, therefore, would become rapidly depleted unless it was regenerated to its active form. In vitro evidence suggests that ascorbate helps regenerate membrane-bound vitamin $\mathrm{E}$, converting the tocopheroxyl radical to its native form and resulting in the formation of an ascorbyl radical (Kagan \& Tyurina, 1998). However, in vivo evidence is currently lacking.

\section{Absorption and transport}

To date the majority of information available on vitamin $\mathrm{E}$ absorption and transport is based on tocopherol (Cohn et al. 1992; Kayden \& Traber, 1993; Herrera \& Barbas, 2001). In 


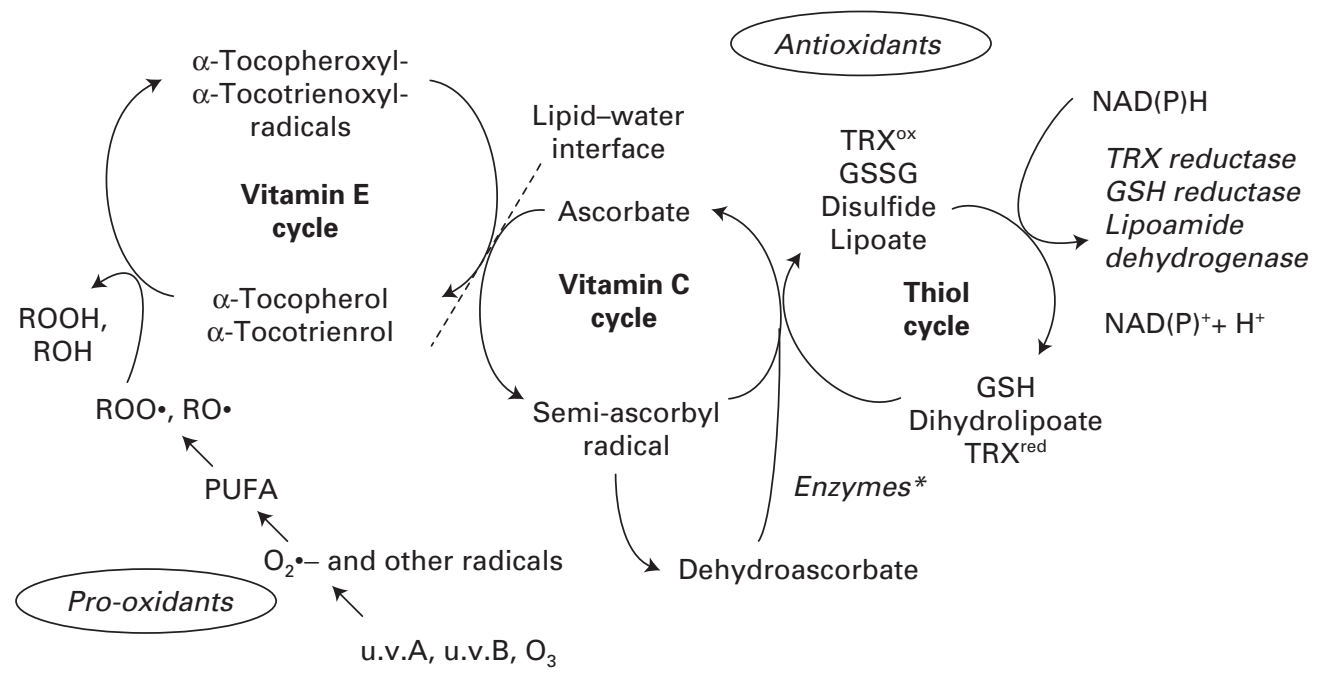

Fig. 2. The antioxidant network showing the interaction among vitamin $E$, vitamin $C$ and thiol redox cycles. PUFA, polyunsaturated fatty acids; GSH, glutathione; TRX, thioredoxin; TRXox, TRX red, oxidised and reduced forms of TRX respectively. * Thiol transferase (glutaredoxin), GSH-dependent dehydroascorbate reductase, protein disulfide isomerase, TRX reductase. (From Packet et al. 2001.)

the small intestine, tocopheryl esters hydrolysed to free vitamin E species are incorporated into mixed micelles due to the action of bile salts and pancreatic juices. Lack of these gastric secretions, as occurs in individuals with conditions such as pancreatitis, cystic fibrosis or choleostatic liver disease, leads to vitamin $\mathrm{E}$ malabsorption and resultant nutrient deficiency symptoms. The micelles enter the enterocyte via passive diffusion and the tocopherols are packaged into chylomicrons along with the phospholipid, cholesterol, triacylglycerol and apolipoprotein moieties. On entry into the circulation via the lymphatic system the chylomicrons are sequentially hydrolysed, due to the action by lipoprotein lipase attached to the capillary endothelium in the target tissue such as muscle and adipose tissue; a proportion of the tocopherol is released and taken up by the endothelial cells. The resulting chylomicron remnants are taken up by the liver by receptor-mediated endocytotic processes.

In contrast to vitamins $\mathrm{A}$ and $\mathrm{D}$, there does not appear to be a specific carrier protein for vitamin $\mathrm{E}$ in the circulation. Instead, vitamin $\mathrm{E}$ is incorporated into lipoprotein particles in a non-specific manner. In hepatic cells tocopherol from chylomicron remnants binds to cytosolic $\alpha$-tocopherol transfer protein $(\alpha-$ TTP; Catignani \& Bieri, 1977; Hosomi et al. 1997), which mediates its transfer to the site of VLDL synthesis (rough endoplasmic reticulum and Golgi apparatus). This $32 \mathrm{kDa}$ protein is expressed almost exclusively in the liver, and recent evidence from animal studies suggests that dietary $\alpha$-tocopherol modulates hepatic $\alpha$-TTP mRNA levels (Fechner et al. 1998). Unlike tocopherol absorption, which is thought to be non-selective with respect to isomer, $\alpha$-TTP displays stereoisomer specificity, with almost exclusive incorporation of $\alpha$-tocopherol into the nascent VLDL particle. Relative affinities of tocopherol analogues for $\alpha$-TTP, calculated from competition studies, are as follows (\%): $\alpha$-tocopherol 100, $\beta$-tocopherol 38, $\gamma$-tocopherol 9, $\delta$-tocopherol 2 (Hosomi et al. 1997). The majority of non- $\alpha$ isomers are excreted via the bile (Traber \& Kayden, 1989). $\alpha$-TTP is now recognised to be the primary determinant of plasma tocopherol levels. Mutations of the $\alpha$-TTP gene lead to reduced plasma and tissue $\alpha$-tocopherol, which may ultimately lead to a severe condition known as ataxia with vitamin E deficiency, with associated neuronal and retinal damage (Traber et al. 1990; Ben Hamida et al. 1993). In a recent study $\alpha$-TTP knockout mice (Ttpa+/- and Ttpa-/-) were used as a model to examine the association between vitamin $\mathrm{E}$ deficiency and atherosclerosis (Terasawa et al. 2000). Plasma and tissue $\alpha$-tocopherol were reduced in a stepwise manner from controls through Ttpa +- to Ttpa-/-, with an absence of liver $\alpha$-TTP in liver homogenates from Ttpa- $/$ and a $50 \%$ reduction in protein level in the Ttpat/- animals. The vitamin E deficiency was associated with increased lesions in the proximal aorta and increased rates of lipid peroxidation. These findings further demonstrate the role of this transfer protein in tocopherol metabolism and, ultimately, in CHD risk.

Approximately $50-70 \%$ of the total secreted VLDL is hydrolysed to LDL, with associated transfer of tocopherols into the LDL fraction (Welty et al. 2000). In the circulation tocopherol exchanges rapidly between the lipoprotein particles, although $>90 \%$ is contained within the LDL and HDL fractions (Behrens et al. 1982). The $75 \mathrm{kDa}$ plasma phospholipid transfer protein facilitates tocopherol exchange between HDL and LDL (Lagrost et al. 1998).

The mechanisms of peripheral cellular uptake of vitamin E are poorly understood, although simultaneous uptake of tocopherol via receptor-mediated lipoprotein endocytosis, or via fatty acid-binding proteins, may be involved. However, recent evidence suggests that specific membrane tocopherol-binding proteins may also mediate tocopherol uptake (Dutta-Roy, 1999). 
Information on intracellular tocopherol transport is currently lacking. Due to its strong hydrophobicity, transfer to cellular sites requires a specific transfer protein. However, it is still unclear how many other $\alpha$ tocopherol-binding proteins exist and which mechanisms regulate tocopherol transfer within peripheral cells. Recently, a novel binding protein, tocopherol-associated protein, has been identified (Stocker et al. 1999; Zimmer et al. 2000; Blatt et al. 2001; Yamauchi et al. 2001). This $46 \mathrm{kDa}$ protein, which displays substantial sequence homology to $\alpha$-TTP, is ubiquitously expressed, although the highest levels have been observed in the liver, brain and prostate (Zimmer et al. 2000). It is suggested that this protein plays an important general role in intracellular tocopherol metabolism. Structural analysis of tocopherolassociated protein suggested that it is a member of the widespread SEC14-like protein family, which plays a role in phospholipid exchange in the cell. Recent ligand competition studies indicate that tocopherol-associated protein binds to $\alpha$-tocopherol but not other tocopherol isomers (Blatt et al. 2001). Although research is at an early stage, it is likely that tocopherol-associated protein will prove an important molecule with respect to cellular tocopherol events.

\section{Cell signalling}

\section{Protein kinase $C$ and protein phosphatase $2 A$ activity}

Since the discovery of the tocopherols and tocotrienols, it is their antioxidant properties that have received most attention. It is now clear, however, that the role of vitamin $\mathrm{E}$ goes beyond its antioxidant function. The first observation of a cell signalling role for vitamin $\mathrm{E}$ was the finding by Angelo Azzi's group (Boscoboinik et al. 1991a,b) that smooth muscle cell proliferation and protein kinase $\mathrm{C}$
(PKC) activity are inhibited by $\alpha$-tocopherol (see Table 1). The inhibition of smooth muscle cell proliferation was specific to $\alpha$-tocopherol; Trolox, phytol, $\beta$-tocopherol and $\alpha$-tocopheryl esters had no effect. As $\alpha$-tocopherol and $\beta$-tocopherol have very similar free radical-scavenging activities, the mechanism by which $\alpha$-tocopherol acts on PKC is not thought to be related to its antioxidant properties. Subsequent studies have shown that PKC is inhibited in a number of other cell types, including monocytes (Devaraj et al. 1996), neutrophils (Kanno et al. 1995), fibroblasts (Hehenberger \& Hansson, 1997) and mesangial cells (Tada et al. 1997). Most importantly, this inhibition of PKC by $\alpha$ tocopherol occurs at concentrations close to those measured in human plasma (Azzi et al. 2001). Anti-proliferative effects of vitamin E were not seen for HeLA cells, suggesting that there are different cell-specific pathways of cellular proliferation in which vitamin $\mathrm{E}$ can act (Fazzio et al. 1997). In addition, the inhibition of PKC was not related to a direct interaction of $\alpha$-tocopherol with the enzyme or with a diminution of its expression. Instead, PKC inhibition by $\alpha$-tocopherol is linked to the activation of a protein phosphatase $2 \mathrm{~A}$, which in turn dephosphorylates PKC- $\alpha$ and thereby inhibits its activity (Clement et al. 1997; Ricciarelli et al. 1998). An inhibitory effect of $\alpha$-tocopherol on PKC may be seen only at the cellular level and is not evident with recombinant PKC.

\section{Cyclo-oxygenase}

Cyclo-oxygenase (COX) has two isoforms, COX-1 and COX-2. COX-1 is constitutively expressed in most cells, whereas COX-2 is regulated by growth factors, tumour promoters, cytokines, glucocorticoids and lipopolysaccharides. COX converts arachidonic acid into prostaglandin $\mathrm{E}_{2}$, the precursor of thromboxane and eicosanoid synthesis. High levels of COX-2 in epithelial cells are associated with

Table 1. Important findings in experimental vitamin $E$ research

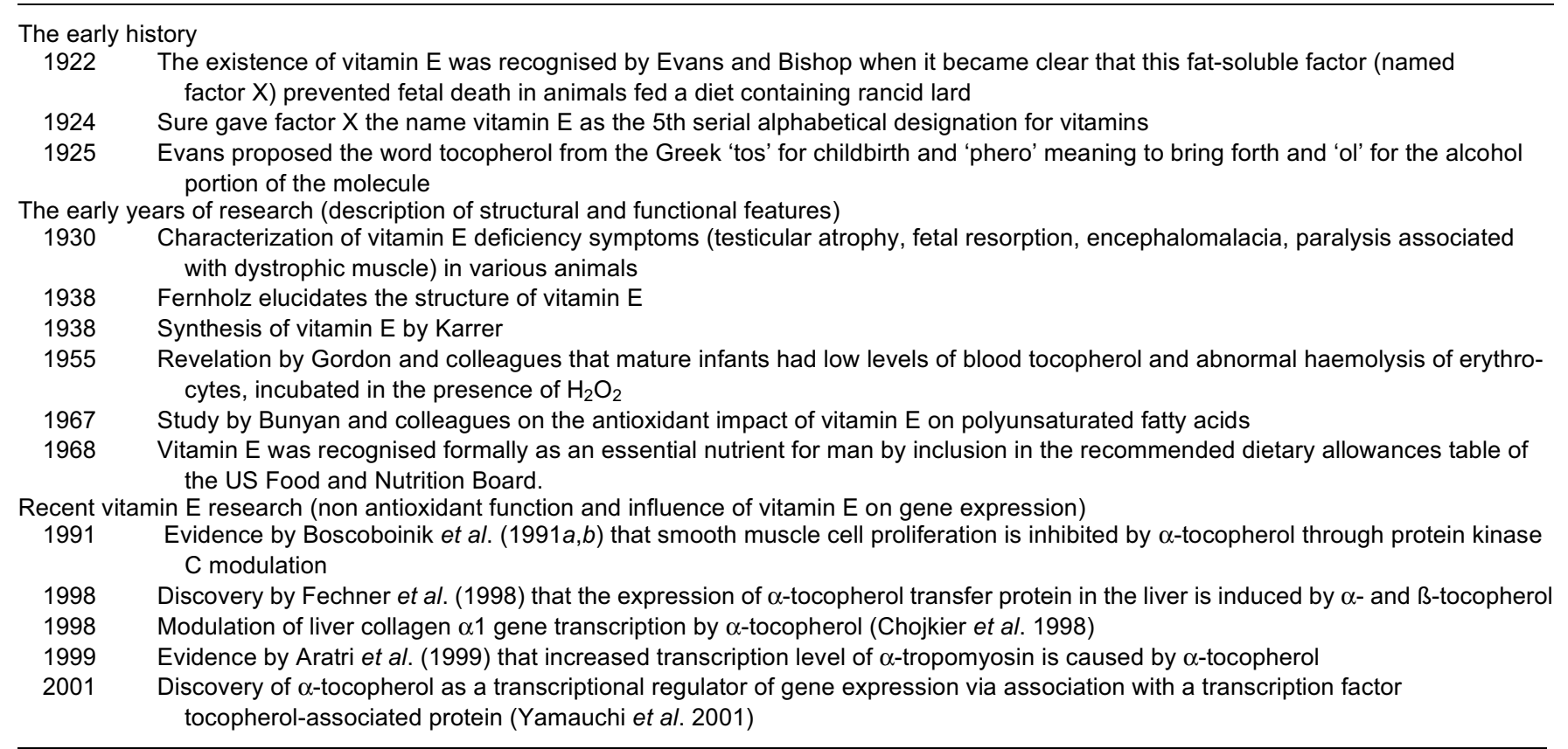


the inhibition of apoptosis, and overexpression of COX-2 has been implicated in the pathogenesis of neoplastic diseases. An up-regulation of COX-2 transcription has been shown in most human colo-rectal cancers (Fosslien, 2001). Interestingly changes in arachidonic acid metabolism stimulate cell proliferation via activation of $\mathrm{PKC}$, indicating that PKC might be one of the primary signalling pathways through which certain tumours are initiated or maintained. In recent years, a role for COX-2 in atherogenesis has been identified. Immunocytochemical studies using anti-COX-2 have shown that COX-2 is localised to macrophages in atherosclerotic lesions of patients with coronary artery disease (Baker et al. 1999).

In monocytes derived from aged mice it has been shown that a vitamin E-induced decrease in prostaglandin $E_{2}$ production is mediated via decreased COX activity (Wu et al. 2001). However, vitamin $\mathrm{E}$ has no effect on $\mathrm{COX}$ mRNA and protein levels, indicating a post-translational regulation of the COX enzyme. Non- $\alpha$-tocopherol homologues were like $\beta$-tocopherol, also effective in inhibiting COX activity, but the extent of inhibition varied in proportion to their antioxidant capacity, suggesting that an antioxidant mechanism may be involved.

It has been shown in lipopolysaccharide-stimulated RAW264.7 macrophages and interleukin 1 $\beta$-treated A549 human epithelial cells that $\gamma$-tocopherols inhibited the production of prostaglandin $\mathrm{E}_{2}$ due to a direct inhibition of COX-2 (Jiang et al. 2000). Furthermore, the major metabolite of dietary $\gamma$-tocopherol also exhibited an inhibitory effect in these cells. In contrast, $\alpha$-tocopherol at $50 \mu \mathrm{M}$ slightly reduced $(25 \%)$ prostaglandin $\mathrm{E}_{2}$ formation in macrophages, but had no effect in epithelial cells. Similar to the previously mentioned study, the inhibitory effect of $\gamma$-tocopherol and 2,7,8-trimethyl-2-(betacarboxyethyl)-6-hydroxychroman stemmed from their inhibition of COX-2 activity, rather than from affecting protein expression or substrate availability, and appeared to be independent of their antioxidant activity.

\section{Nuclear factor kappa $B$}

The transcription factors of the nuclear factor kappa B $(\mathrm{NF}-\kappa \mathrm{B}) /$ Rel family control the expression of a spectrum of different genes involved in inflammatory and proliferative responses. The typical NF- $\mathrm{KB}$ dimer is composed of the p50 and p65 subunits, and it is present in an inactive form in the cytosol bound to the inhibitory proteins, NF- $\mathrm{KB}$ inhibitory unit. Following activation by various stimuli, including inflammatory or hyperproliferative cytokines, reactive oxygen species and bacterial wall components, the phosphorylation and proteolytic removal of NF- $\kappa \mathrm{B}$ inhibitory unit from the complex occurs. Activated NF- $\kappa B$ then immediately enters the nucleus where it interacts with regulatory kappa $\mathrm{B}$ elements in the promoter and enhancer regions, thereby controlling the transcription of inducible genes (Baeuerle \& Baltimore, 1996; Baeuerle \& Henkel,

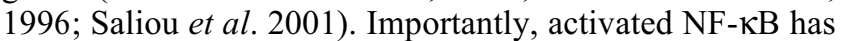
been identified in situ in human atherosclerotic plaques, but not in cells of normal vessels devoid of atherosclerosis (Brand et al. 1996), as well as in an arterial injury model (Lindner \& Collins, 1996). Furthermore, NF- $\kappa \mathrm{B}$ is activated by an atherogenic diet (Liao et al. 1993), and by oxidised LDL (Brand et al. 1997) and advanced glycation endproducts (Yan et al. 1994). Cumulatively, these observations suggest a key role for NF- $\mathrm{NB}$ in atherogenesis.

A spectrum of key genes known to be involved in the development of atherosclerosis have been shown to be regulated by $\mathrm{NF}-\kappa \mathrm{B}$, including the genes encoding for tumour necrosis factor $\alpha$, interleukin 1 , the macrophage or granulocyte colony-stimulating factor, monocyte chemoattractant protein-1 (MCP-1), c-myc and the adhesion molecules vascular cell adhesion molecule-1 (VCAM-1) and intracellular adhesion molecule-1 (ICAM-1; Rimbach et al. 2000; Collins \& Cybulski, 2001). In the early stages of an atherosclerotic lesion different types of cells (macrophages, smooth muscle cells and endothelial cells) interact, causing a loss of homeostasis and a self-propagating system leading to dysfunction and lesion development in the artery wall (Rimbach et al. 2001). Fig. 3 shows a sketch of the regulation of $\mathrm{NF}-\kappa \mathrm{B}$ activation; some of the major genes involved in atherogenesis are also listed.

Several lines of evidence, including the inhibition caused by various antioxidants, suggest that $N F-\kappa B$ is subject to redox regulation. Since it has a pivotal role in the inflammatory response, a major effort has focused on developing therapeutic agents that regulate $\mathrm{NF}-\kappa \mathrm{B}$ activity. In this scenario vitamin E may play an important role, either by directly affecting key steps in the activation pathway of $\mathrm{NF}-\kappa \mathrm{B}$, or by modulating the intracellular redox status which is, in turn, one of the major determinants of NF- $\kappa B$ activation. Consistent experimental data is accumulating to suggest that the anti-inflammatory properties of vitamin $\mathrm{E}$ are in part due to its ability to down regulate NF- $\kappa B$. Suzuki $\&$ Packer (1993) examined the effect of vitamin E derivatives on tumour necrosis factor $\alpha$-induced NF- $\kappa B$ activation. Incubation of human Jurkat T-cells with tocopheryl acetate or $\alpha$-tocopheryl succinate exhibited a concentrationdependent inhibition of NF- $\kappa \mathrm{B}$ activation. Similarly, gelshift studies with the macrophage cell line THP-1 pretreated with $\alpha$-tocopheryl succinate and then activated with lipopolysaccharide showed an inhibition of NF- $\kappa \mathrm{B}$ activity by $43 \%$ at $50 \mu \mathrm{M} \alpha$-tocopheryl succinate $v$. the $\alpha$-tocopheryl succinate-untreated group (Nakamura et al. 1998). However, $\alpha$-tocopherol had no effect on NF- $\kappa B$ activity. Vitamin E transport was analysed in this study by simultaneous determination of vitamin $\mathrm{E}$ and its derivatives using HPLC. The vitamin E recovered from culture pellets showed that approximately the same amounts of $\alpha$ tocopherol and $\alpha$-tocopheryl succinate had been transferred, and both vitamin derivatives were recovered in the unchanged form. These observations indicate that unchanged $\alpha$-tocopheryl succinate may itself inhibit NF- $\kappa \mathrm{B}$ activation and/or translocation to the nucleus.

\section{a-Tropomyosin, cell adhesion proteins, chemokines and scavenger receptors}

An involvement of tropomyosin in the progression of restenosis has been suggested (Kocher et al. 1991). Early after balloon injury smooth muscle cells that have migrated into the intima contain decreased amounts of tropomyosin, whereas late after balloon injury tropomyosin returns 


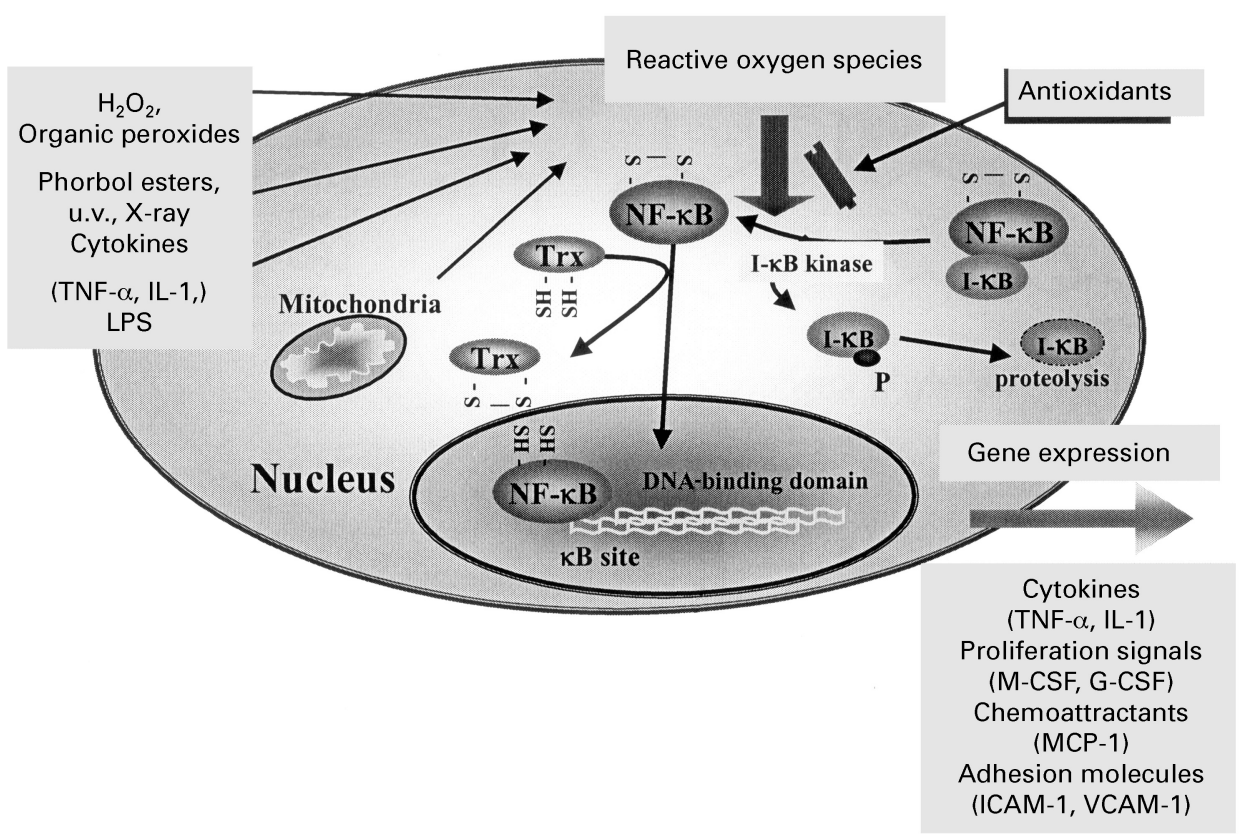

Fig. 3. Regulation of nuclear factor kappa $B(N F-\kappa B)$ activity. TNF- $\alpha$, tumour necrosis factor $\alpha$; IL-1, interleukin 1; M-CSF, G-CSF, macrophage and granulocyte colony-stimulating factor respectively; MCP-1 monocyte chemoattractant protein-1; ICAM-1, intracellular adhesion molecule-1; VCAM-1, vas-

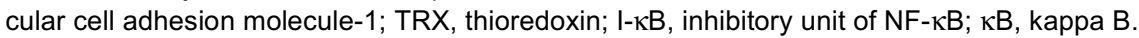

towards normal values. Aratri et al. (1999) reported induction of $\alpha$-tropomyosin expression in rat vascular smooth muscle cells by $\alpha$-tocopherol using differential display techniques. No significant changes in mRNA levels were observed when B-tocopherol was used. The authors suggest that the overexpression of tropomyosin induced by $\alpha$-tocopherol may decrease the contractility of smooth muscle cells, and hence form the molecular basis for the hypotensive effect of vitamin $\mathrm{E}$.

Activation of endothelial cells results in release of vascular cytokines such as interleukin 1 and tumour necrosis factor $\alpha$. These cytokines in turn induce the expression of cell surface adhesion molecules such as VCAM-1 and ICAM-1, which are centrally involved in the endothelial recruitment of neutrophils (Cybulski \& Gimbrone, 1991). Focal expression of ICAM-1 and VACM-1 has been reported in arterial endothelium overlying early foam cell lesions in both dietary and genetic models of atherosclerosis in rabbits (Thiery et al. 1996). This expression, together with the activation of MCP-1, leads to infiltration of mononuclear cells into the wall and it is widely supposed to result in an increase in the oxidation and scavenging of LDL, formation of lipid-laden foam cells and development or progression of atherosclerotic plaques (Rubanyi, 1993).

As mentioned earlier, transcription of ICAM-1, VCAM-1 and MCP-1 is dependent, at least in part, on the activation of NF-KB. Cell culture studies have shown that treatment of endothelial cells with oxidised LDL increases expression of mRNA and proteins levels of ICAM-1 and VCAM-1 (Yoshida et al. 2000). However, pretreatment with $\alpha$ tocopherol reduced cell adhesion protein expression in a dose-dependent manner. Consistent with this finding, adherence of polymorphonuclear leucocytes or mononuclear leucocytes to endothelial cells activated by oxidised LDL (which is much higher than adherence to unstimulated endothelial cells) was reduced by supplementation of the endothelial cells with $\alpha$-tocopherol. Furthermore, interleukin 1 $1 \beta$-induced production of MCP-1 was dosedependently suppressed by enrichment of human endothelial cells with vitamin E (Zapolska-Downar et al. 2000 ). From this and other studies it is suggested that the putative anti-atherogenic effect of $\alpha$-tocopherol may in part be due to a down-regulation of cell adhesion proteins and chemokines. Despite evidence that vitamin E down regulates cell adhesion proteins in vitro, in vivo evidence is currently lacking.

Ricciarelli et al. (2000) have recently demonstrated that the CD36 scavenger receptor, which transports oxidised LDL into the cytosol, is expressed in human smooth muscle cells. Interestingly, $\alpha$-tocopherol inhibited the uptake of oxidised LDL by a mechanism involving down-regulation of CD36 mRNA and protein expression. It is hypothesised that beneficial cardiovascular effects of $\alpha$-tocopherol are at least in part mediated by lowering the uptake of oxidised LDL, which subsequently results in a reduction in foam cell formation.

\section{Nitric oxide and platelet aggregation}

NO produced by the endothelial NO synthase is a pivotal molecule in the regulation of vascular tone. Additionally, its production suppresses expression of pro-inflammatory cytokines, adhesion molecules (De Caerina et al. 1995) and MCP-1 (Busse \& Fleming, 1995). It also inhibits platelet 
adhesion to the endothelium (De Graaf et al. 1992), can modify the permeability of the arterial wall (CardonnaSanclemente \& Born, 1995), suppresses vascular smooth muscle cell proliferation and migration (Garg \& Hassid, 1989), and can act as an antioxidant (Patel et al. 2000). The major risk factors for atherosclerosis (age, Matz et al. 2000; hypercholesterolaemia, Stroes et al. 1995; diabetes, Williams et al. 1996; hypertension, Panza et al. 1995; smoking, Celermajer et al. 1993; low birth weight, Leeson et al. 1997), are all associated with impaired NO activity, often before appreciable disease develops. In rabbits inhibition of NO production accelerates experimental atherosclerosis (Naruse et al. 1994), whilst increases in NO synthesis reduce it (Cooke et al. 1992). Importantly,

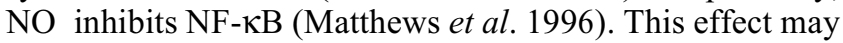
account for its influence on the transcription of genes for adhesion proteins, MCP-1 and others. The postulation of key roles for both $\mathrm{NO}$ and $\mathrm{NF}-\kappa \mathrm{B}$ is therefore not self-contradictory.

There is evidence from studies in rabbits that vitamin $\mathrm{E}$ reverses the well-established deleterious effects of hypercholesterolaemia on NO activity. Stewart-Lee et al. (1994) found that relaxation in response to acetylcholine, an NOdependent phenomenon, in the carotid artery was reduced after 4 weeks of diet-induced hypercholesterolaemia, but was restored by the addition of $2 \mathrm{~g} \alpha$-tocopheryl acetate $/ \mathrm{kg}$ to the diet. Andersson et al. (1994) obtained a similar result for the coronary circulation. The mechanisms underlying this effect are a matter of controversy. It has been suggested that inactivation of $\mathrm{NO}$ by reactive oxygen species is increased during hypercholesterolaemia and reduced by vitamin E (Andersson et al. 1994; Stewart-Lee et al. 1994). However, Böger et al. (1998) found that vitamin E did not reduce reactive oxygen species release by aortic tissue from cholesterol-fed rabbits; instead, they suggested its protective effect on the NO pathway was related to its inhibition of LDL oxidation. Since PKC inhibits NO (Davda et al. 1994), another possible mechanism arises from the observation that hypercholesterolaemia increases PKC levels in rabbit aortic smooth muscle, and this effect is reduced by vitamin $\mathrm{E}$ (Özer \& Azzi, 2000).

Whatever the mechanism, protective effects of vitamin $\mathrm{E}$ on NO function might be expected to reduce atherosclerosis in hypercholesterolaemic rabbits. Although many studies have found such an effect (for example, see Williams et al. 1992; Böger et al. 1998; Schwenke \& Behr, 1998), other studies have not (for example, see Freubis et al. 1995) and some studies have shown an increase in the extent and severity of lesions (Godfried et al. 1989). Keaney et al. (1994) obtained an interesting result which may in part account for these discrepancies; while $1 \mathrm{~g} \alpha$-tocopherol/ $\mathrm{kg}$ diet protected against the inhibitory effect of hypercholesterolaemia on the NO pathway, $10 \mathrm{~g} \alpha$-tocopherol $/ \mathrm{kg}$ diet markedly increased it, and also increased the severity of lesions, despite the fact that the oxidisability of LDL was still reduced. Possible mechanisms include pro-oxidant effects of $\alpha$-tocopherol, or reactions of $\alpha$-tocopherol with NO to give the tocopheroxyl radical (Keaney et al. 1994).

Li et al. (2001) studied the effect of different isoforms of vitamin $\mathrm{E}$ on $\mathrm{NO}$ activity and platelet aggregation in human platelet-rich plasma. All three isoforms tested $(\alpha-, \beta$ - or $\delta$-tocopherol) markedly decreased ADP-induced platelet aggregation and increased NO release in a dose-dependent manner. The isoforms did not affect constitutively-expressed NO synthase protein expression, but increased constitutivelyexpressed NO synthase phosphorylation. Furthermore, it has been demonstrated in human subjects that oral supplementation with $\alpha$-tocopherol $(400-1200 \mathrm{mg} / \mathrm{d})$ resulted in an increase in platelet tocopherol concentration that correlated with marked inhibition of polymorphonuclear leucocytemediated platelet aggregation (Freedman et al. 1996). Platelets derived from these subjects also demonstrated apparent complete inhibition of PKC. These findings represent another potential mechanism by which tocopherol could prevent the development of coronary artery disease.

\section{Differential gene expression}

Microarray technology enables us to investigate genes differentially expressed in response to an antioxidant treatment, thereby offering the possibility of greater insight into the biological properties of antioxidants (Watanabe et al. 2001). To examine the molecular events associated with Se and vitamin E deficiency in rats, cDNA array technology has been applied to define the transcriptional response in rat liver after 7 weeks on a Se- and/or vitamin E-deficient diet (Fischer et al. 2001). Atlas ${ }^{\mathrm{TM}}$ Rat cDNA Toxicology Array II from Clontech (Oxford, UK) was used to monitor simultaneously the expression of 465 genes (Table 2); a change of $\geq 2$-fold was considered significant $(P<0 \cdot 05)$. Vitamin $\mathrm{E}$ deficiency alone did not significantly affect any of the genes monitored. Of course, other genes not present on the cDNA membrane could have been differentially regulated by vitamin E. Additionally, tissues other than liver might be more susceptible to vitamin E-induced changes in differential gene expression.

In addition to a 13.9-fold down-regulation of the cellular glutathione peroxidase gene, Se deficiency alone was accompanied with an increase in the expression of UDPglucuronosyltransferase 1 and bilirubin UDP-glucuronosyltransferase isoenzyme 2. These two enzymes are known to have an important function in the detoxification of xenobiotics in liver. Similarly, rat liver cytochrome P450 $4 \mathrm{~B} 1$, which is also involved in xenobiotic metabolism and inducible by glucocorticoids, was induced 2.3-fold. The mRNA levels of arachidonate 12-lipoxygenase were $2 \cdot 4$-fold higher in Se-deficient animals than in controls. It has been shown that arachidonate 12-lipoxygenase and phospholipid hydroperoxide glutathione peroxidase are opposing enzymes balancing the intracellular concentration of hydroperoxy lipids; an inhibition of phospholipid hydroperoxide glutathione peroxidase activity increases the enzymic catalysis of arachidonate 12-lipoxygenase (Chen et al. 2000).

In combined Se and vitamin E deficiency, $5 \%$ of all genes monitored were differentially expressed. The double deficiency was characterised by down-regulation of genes that inhibit programmed cell death, including defenderagainst-cell-death 1 protein, inhibitor of apoptosis protein 1 and Bcl2-L1. Furthermore, the expression level of earlygrowth-response protein 1, known as a suppressor of growth and transformation and an inducer of apoptosis, was 
Table 2. Selection of selenium and vitamin $E$ deficiency-related changes ( $\Delta-\mathrm{Se}-\mathrm{E})$ in gene expression in rat liver

\begin{tabular}{|c|c|c|c|}
\hline \multicolumn{2}{|c|}{ GenBank accession $\Delta-$ Se-E (fold) } & Gene & Function \\
\hline Y13336 & $\downarrow 2.0$ & Defender against cell death 1 protein & Protection against apoptosis \\
\hline U72350 & $\downarrow 3.2$ & $\mathrm{Bcl} 2-\mathrm{L} 1$ & Protection against apoptosis \\
\hline M22413 & $\downarrow 2.0$ & Carbonic anhydrase III & Antioxidant, protection against apoptosis \\
\hline D90345 & $\downarrow 2.2$ & T-complex protein 1 alpha subunit & Chaperone, folding of proteins \\
\hline X82021 & $\downarrow 2.2$ & HSC70-interacting protein & Stabilisation of the chaperone HSC70 \\
\hline J04154 & $\uparrow 2.1$ & Early growth response protein 1 & Suppression of growth and induction of apoptosis \\
\hline U77129 & $\uparrow 2.0^{*}$ & SPS1/Ste20 homologue KHS1 & Transducer of signals in Mitogen-activated protein-kinase pathway \\
\hline \multicolumn{4}{|c|}{ Antioxidant defense or stress response or inflammation: } \\
\hline X12367 & $\downarrow 18.8$ & Cellular glutathione peroxidase I & Peroxide detoxification \\
\hline J05181 & $\downarrow 3.4$ & $\gamma$-Glutamylcysteine synthetase & Glutathione synthesis \\
\hline U22424 & $\downarrow 2.2$ & $11-\beta$-Hydroxysteroid dehydrogenase 2 & Conversion of corticosterone into 11-dehydrocorticosterone \\
\hline J00734 & $\uparrow 2.3$ & Fibrinogen $\gamma$ chain & Acute-phase protein \\
\hline S65838 & $\uparrow \mathbf{3 . 6}$ & Metallothionein 1 & Acute-phase protein, antioxidant \\
\hline
\end{tabular}

$\downarrow$ down-regulation; $\uparrow$, up-regulation.

${ }^{*}$ Gene signal at background level in one array.

increased 2-fold. Carbonic anhydrase III, which was reported recently to play a role as an antioxidant preventing $\mathrm{H}_{2} \mathrm{O}_{2}$-inducible apoptosis (Raisanen et al. 1999), was down regulated 2-fold. A stronger tendency towards negative cell cycle progression in livers of double-deficient rats was further suggested by the down-regulation of nucleophosmin and G1/S-specific cyclin D1, which has been characterised as an important signal in anti-apoptotic mechanisms.

Combined Se and vitamin E deficiency also resulted in an induction of acute-phase proteins (metallothionein, DTdiaphorase, alpha-1 acid glycoprotein) and serine proteinase inhibitor-3. A further indication of pro-inflammatory responses in rats fed diets deficient in Se plus vitamin E is that they exhibited higher expression of the fibrinogen $\gamma$ chain, which has been shown to be up regulated in the rat liver during inflammation. The induction of proinflammatory genes was accompanied by a concerted depression of the anti-inflammatory enzyme 11- $\beta$-hydroxysteroid dehydrogenase 2 , which converts the glucocorticoid corticosterone to its inactive 11-dehydro form in the rat, thereby controlling glucocorticoid access to receptors.

Analysis of differential gene expression in the endothelium is critical to our understanding of the sequence of events leading to the formation of atherosclerotic lesions. In order to address this question and gain a more comprehensive overview of the molecular mechanisms involved in the contribution of oxidised LDL to the pathophysiology of atherosclerosis, we determined a global gene expression profile in primary human endothelial cells in the presence and absence of oxidised LDL using high-density cDNA membranes. Gene expression analysis again focused on mRNA that showed $>2$-fold change in their expression level. Employing this criterion seventy-eight of 588 genes were differentially expressed. Oxidised LDL altered the expression of genes encoding for transcription factors (e.g. GATA-2), cell receptors (e.g. advanced glycation endproduct-related receptor precursor), adhesion molecules (e.g. P-selectin), extracellular matrix proteins (e.g. matrix metalloproteinase 9) and enzymes involved in cholesterol metabolism (e.g. farnesyltransferase $\beta$ ). Interestingly, in primary human endothelial cells some of the genes, which were up regulated by oxidised LDL, were down regulated by vitamin $\mathrm{E}$. The experimental strategy identified several novel oxidised LDL- and vitamin E-sensitive genes. Cardiovascular specific DNA arrays are an important platform for obtaining a global genetic portrait and understanding the complex molecular events leading to atherosclerosis.

\section{References}

Andersson TLG, Matz J, Ferns GAA \& Änggård EE (1994) Vitamin E reverses cholesterol-induced endothelial dysfunction in the rabbit coronary circulation. Atherosclerosis 111, 39-45.

Aratri E, Spycher SE, Breyer I \& Azzi A (1999) Modulation of alpha-tropomyosin expression by alpha-tocopherol in rat vascular smooth muscle cells. FEBS Letters 447, 91-94.

Azzi A, Breyer I, Feher M, Ricciarelli R, Stocker A, Zimmer S \& Zingg J (2001) Nonantioxidant functions of alpha-tocopherol in smooth muscle cells. Journal of Nutrition 131, 378S-381S.

Baeuerle PA \& Baltimore D (1996) NF-kappa B: ten years after. Cell 87, 13-20.

Baeuerle PA \& Henkel T (1996) Function and activation of NFkappa B in the immune system. Annual Review of Immunology 12, 141-179.

Baker CS, Hall RJ, Evans TJ, Pomerance A, Maclouf J, Creminon C, Yacoub MH \& Polak JM (1999) Cyclooxygenase-2 is widely expressed in atherosclerotic lesions affecting native and transplanted human coronary arteries and colocalizes with inducible nitric oxide synthase and nitrotyrosine particularly in macrophages. Arteriosclerosis Thrombosis and Vascular Biology 19, 646-655. 
Behrens WA, Thompson JN \& Madere R (1982) Distribution of alpha-tocopherol in human plasma lipoproteins. American Journal of Clinical Nutrition 35, 691-696.

Ben Hamida C, Doerflinger N, Belal S, Linder C, Reutenauer L, Dib C et al. (1993) Localization of Friedreich ataxia phenotype with selective vitamin $\mathrm{E}$ deficiency to chromosome $8 \mathrm{q}$ by homozygosity mapping. Nature Genetics 5, 195-200.

Blatt DH, Leonard SW \& Traber MG (2001) Vitamin E kinetics and the function of tocopherol regulatory proteins. Nutrition $\mathbf{1 7}$, 799-805.

Böger RH, Bode-Böger SM, Phivthong-ngam L, Brandes RP, Schwedhelm E, Mügge A, Böhme D, Tsikas D \& Frölich JC (1998) Dietary L-arginine and $\alpha$-tocopherol reduce vascular oxidative stress and preserve endothelial function in hypercholesterolemic rabbits via different mechanisms. Atherosclerosis 141, 31-44.

Boscoboinik D, Szewczyk A \& Azzi A (1991a) Alpha-tocopherol (vitamin E) regulates vascular smooth muscle cell proliferation and protein kinase $\mathrm{C}$ activity. Archives of Biochemistry and Biophysics 286, 264-269.

Boscoboinik D, Szewczyk A, Hensey C \& Azzi A (1991b) Inhibition of cell proliferation by alpha-tocopherol. Role of protein kinase C. Journal of Biological Chemistry 266, 6188-6194.

Brand K, Page S, Rogler G, Bartsch A, Brandl R, Knuechel R, Page M, Kaltschmidt C, Baeuerle PA \& Neumeier D (1996) Activated transcription factor nuclear factor-kappa B is present in the atherosclerotic lesion. Journal of Clinical Investigation 97, 1715-1722.

Brand K, Page S, Walli AK, Neumeier D \& Baeuerle PA (1997) Role of nuclear factor-kappa B in atherogenesis. Experimental Physiology 82, 297-304.

Brigelius-Flohe R \& Traber MG (1999) Vitamin E: function and metabolism. FASEB Journal 13, 1145-1155.

Busse R \& Fleming I (1995) Regulation and functional consequences of endothelial nitric oxide formation. Annals of Medicine 27, 331-340.

Cardonna-Sanclemente LE \& Born GVR (1995) Effect of inhibition of nitric oxide synthesis on the uptake of LDL and fibrinogen by arterial walls and other organs of the rats. British Journal of Pharmacology 114, 1490-1494.

Catignani GL \& Bieri JG (1977) Rat liver alpha-tocopherol binding protein. Biochimica et Biophysica Acta 497, 349-357.

Celermajer DS, Sorensen KE, Georgakopoulos D, Bull C, Thomas O, Robinson J \& Deanfield JE (1993) Cigarette smoking is associated with dose-related and potentially reversible impairment of endothelium-dependent dilation in healthy young adults. Circulation 88, 2149-2155.

Chen CJ, Huang HS, Lin SB \& Chang WC (2000) Regulation of cyclooxygenase and 12-lipoxygenase catalysis by phospholipid hydroperoxide glutathione peroxidase in A431 cells. Prostaglandins Leukotrienes and Essential Fatty Acids 62, 261-268.

Clement S, Tasinato A, Boscoboinik D \& Azzi A (1997) The effect of alpha-tocopherol on the synthesis, phosphorylation and activity of protein kinase $\mathrm{C}$ in smooth muscle cells after phorbol 12-myristate 13-acetate down-regulation. European Journal of Biochemistry 246, 745-749.

Cohn W, Gross P, Grun H, Loechleiter F, Muller DP \& Zulauf M (1992) Tocopherol transport and absorption. Proceedings of the Nutrition Society 51, 179-188.

Collins T \& Cybulski MI (2001) NF-kB: pivotal mediator or innocent bystander in atherogenesis. Journal of Clinical Investigation 107, 255-264.

Cooke JP, Singer AH, Tsao P, Zera P, Rowan RA \& Bilingam ME (1992) Antiatherogenic effects of L-arginine in the hypercholesterolemic rabbit. Journal of Clinical Investigation 90, 1168-1172.

Cybulski MI \& Gimbrone MA (1991) Endothelial expression of a mononuclear leukocyte adhesion molecule during atherogenesis. Science 251, 788-791.

Davda RK, Chandler LJ \& Guzman NJ (1994) Protein kinase C modulates receptor-independent activation of endothelial nitric oxide synthase. European Journal of Pharmacology 266, 237-244.

De Caerina R, Libby P, Peng HB, Thannickal VJ, Rajavashisth TB, Gimbrone MAJ, Shin WS \& Liao JK (1995) Nitric oxide decreases cytokine-induced endothelial activation: nitric oxide selectively reduces endothelial expression of adhesion molecules and proinflammatory cytokines. Journal of Clinical Investigation 96, 60-68.

De Graaf JC, Banga JD, Moncado S, Palmer RM, de Groot PG \& Sixma JJ (1992) Nitric oxide functions as an inhibitor of platelet adhesion under flow conditions. Circulation 85, 2284-2290.

Devaraj S, Li D \& Jialal I (1996) The effects of alpha tocopherol supplementation on monocyte function. Decreased lipid oxidation, interleukin 1 beta secretion, and monocyte adhesion to endothelium. Journal of Clinical Investigation 98, 756-763.

Dutta-Roy AK (1999) Molecular mechanism of cellular uptake and intracellular translocation of alpha-tocopherol: role of tocopherol-binding proteins. Food and Chemical Toxicology 37, 967-971.

Fazzio A, Marilley D \& Azzi A (1997) The effect of alphatocopherol and beta-tocopherol on proliferation, protein kinase $\mathrm{C}$ activity and gene expression in different cell lines. Biochemistry and Molecular Biology International 41, 93-101.

Fechner H, Schlame M, Guthmann F, Stevens PA \& Rustow B (1998) Alpha- and delta-tocopherol induce expression of hepatic alpha-tocopherol-transfer-protein mRNA. Biochemical Journal 331, 577-581.

Fischer A, Pallauf J, Gohil K, Weber SU, Packer L \& Rimbach G (2001) Effect of selenium and vitamin E deficiency on differential gene expression in rat liver. Biochemical and Biophysical Research Communications 285, 470-475.

Fosslien E (2001) Review: molecular pathology of cyclooxygenase-2 in cancer-induced angiogenesis. Annals of Clinical and Laboratory Science 31, 325-348.

Freedman JE, Farhat JH, Loscalzo J \& Keaney JF Jr (1996) Alphatocopherol inhibits aggregation of human platelets by a protein kinase C-dependent mechanism. Circulation 94, 2434-2440.

Freubis J, Carew TE \& Palinski W (1995) Effect of vitamin E on atherogenesis in LDL receptor-deficient rabbits. Atherosclerosis 117, 217-224.

Garg UC \& Hassid A (1989) Nitric oxide generation vasodilators and 8-bromo-cyclic guanosine monophosphate inhibit mitogenesis and proliferation of cultured rat vascular smooth muscle cells. Journal of Clinical Investigation 83, 1774-1777.

Godfried SL, Combs GF Jr, Saroke JM \& Dillingham LA (1989) Potentiation of atherosclerotic lesions in rabbits by high dietary levels of vitamin E. British Journal of Nutrition 61, 607-617.

Halliwell B (1996) Antioxidants in human health and disease. Annual Review of Nutrition 16, 33-50.

Hehenberger K \& Hansson A (1997) High glucose-induced growth factor resistance in human fibroblasts can be reversed by antioxidants and protein kinase C-inhibitors. Cell Biochemistry and Function 15, 197-201.

Herrera E \& Barbas C (2001) Vitamin E: action, metabolism and perspectives. Journal of Physiology and Biochemistry 57, 43-56.

Hosomi A, Arita M, Sato Y, Kiyose C, Ueda T, Igarashi O, Arai H \& Inoue K (1997) Affinity for alpha-tocopherol transfer protein as a determinant of the biological activities of vitamin $\mathrm{E}$ analogs. FEBS Letters 409, 105-108. 
Ingold KU, Webb AC, Witter D, Burton GW, Metcalfe TA \& Muller DP (1987) Vitamin E remains the major lipid-soluble, chain-breaking antioxidant in human plasma even in individuals suffering severe vitamin E deficiency. Archives of Biochemistry and Biophysics 259, 224-225.

Jiang Q, Elson-Schwab I, Courtemanche C \& Ames BN (2000) Gamma-tocopherol and its major metabolite, in contrast to alphatocopherol, inhibit cyclooxygenase activity in macrophages and epithelial cells. Proceedings of the National Academy of Sciences USA 97, 11494-11499.

Kagan VE \& Tyurina YY (1998) Recycling and redox cycling of phenolic antioxidants. Annals of the New York Academy of Sciences 854, 425-434.

Kanno T, Utsumi T, Kobuchi H, Takehara Y, Akiyama J, Yoshioka T, Horton AA \& Utsumi K (1995) Inhibition of stimulus-specific neutrophil superoxide generation by alpha-tocopherol. Free Radical Research 22, 431-440.

Kayden HJ \& Traber MG (1993) Absorption, lipoprotein transport, and regulation of plasma concentrations of vitamin $\mathrm{E}$ in humans. Journal of Lipid Research 34, 343-358.

Keaney JF Jr, Gaziano JM, Xu A, Frei B, Curran-Celtano J, Shwaery GT, Loscalzo J \& Vita JA (1994) Low dose $\alpha$-tocopherol worsens endothelial vasodilator function in cholesterol-fed rabbits. Journal of Clinical Investigation 93, 844-851.

Kocher O, Gabbiani F, Gabbiani G, Reidy MA, Cokay MS, Peters H \& Huttner I (1991) Phenotypic features of smooth muscle cells during the evolution of experimental carotid artery intimal thickening. Biochemical and morphologic studies. Laboratory Investigation 65, 459-470.

Lagrost L, Desrumaux C, Masson D, Deckert V \& Gambert P (1998) Structure and function of the plasma phospholipid transfer protein. Current Opinion in Lipidology 9, 203-209.

Leeson CPM, Whincup PH, Cook DG, Donald AE, Papacosta O, Lucas A \& Deanfield JE (1997) Flow mediated dilation in 9- to 11 -year old children - the influence of intrauterine and childhood factors. Circulation 96, 2233-2238.

Li D, Saldeen T, Romeo F \& Metha JL (2001) Different isoforms of tocopherols enhance nitric oxide synthase phosphorylation and inhibit human platelet aggregation and lipid peroxidation: implication in therapy with vitamin E. Journal of Cardiovascular Pharmacology and Therapy 6, 155-161.

Liao F, Andalibi A, deBeer FC, Fogelman AM \& Lusis AJ (1993) Genetic control of inflammatory gene induction and NF-kappa B-like transcription factor activation in response to an atherogenic diet in mice. Journal of Clinical Investigation 91, 2572-2579.

Lindner V \& Collins T (1996) Expression of NF-kappa B and I kappa B-alpha by aortic endothelium in an arterial injury model. American Journal of Pathology 148, 427-438.

Malins DC, Johnson PM, Wheeler TM, Barker EA, Polissar NL \& Vinson MA (2001) Age-related radical-induced DNA damage is linked to prostate cancer. Cancer Research 61, 6025-6028.

Matthews JR, Botting CH, Panico M, Morris HR \& Hay RT (1996) Inhibition of NF-kappa B DNA binding by nitric oxide. Nucleic Acids Research 24, 2236-2242.

Matz RL, Schott C, Stoclet JC \& Andriantsitohaina R (2000) Age-related endothelial dysfunction with respect to nitric oxide, endothelium-dependent hyperpolarizing factor and cyclooxygenase products. Physiological Research 49, 11-18.

Nakamura T, Goto M, Matsumoto A \& Tanaka I (1998) Inhibition of NF-kappa B transcriptional activity by alpha-tocopheryl succinate. Biofactors 7, 21-30.

Naruse K, Shimizu K, Muramatsu M, Toki Y, Miyazaki Y, Okumura K, Hashimoto H \& Ito T (1994) Long-term inhibition of NO synthesis promotes atherosclerosis in the hypercholesterolemic rabbit thoracic aorta. PGH2 does not contribute to impaired endothelium-dependent relaxation. Arteriosclerosis and Thrombosis 14, 746-752.

Özer NK \& Azzi A (2000) Effect of vitamin E on the development of atherosclerosis. Toxicology 148, 179-185.

Packer L, Weber SU \& Rimbach G (2001) Molecular aspects of alpha-tocotrienol antioxidant action and cell signalling. Journal of Nutrition 131, 369S-373S.

Panza JA, Garcia CE, Kilcoyne CM, Quyyumi AA \& Cannon RO 3rd (1995) Impaired endothelium-dependent vasodilation in patients with essential hypertension. Evidence that nitric oxide abnormality is not localized to a single signal transduction pathway. Circulation 91, 1732-1738.

Parthasarathy S, Santanam N, Ramachandran S \& Meilhac O (1999) Oxidants and antioxidants in atherogenesis. An appraisal. Journal of Lipid Research 40, 2143-2157.

Patel RP, Levonen AL, Crawford JH \& Darley-Usma VM (2000) Mechanisms of the pro- and antioxidant actions of nitric oxide in atherosclerosis. Cardiovascular Research 47, 465-474.

Raisanen SR, Lehenkari P, Tasanen M, Rahkila P, Harkonen PL \& Vaananen HK (1999) Carbonic anhydrase III protects cells from hydrogen peroxide-induced apoptosis. FASEB Journal 13, 513-522.

Ricciarelli R, Tasinato A, Clement S, Ozer NK, Boscoboinik D \& Azzi A (1998) alpha-Tocopherol specifically inactivates cellular protein kinase $\mathrm{C}$ alpha by changing its phosphorylation state. Biochemical Journal 334, 243-249.

Ricciarelli R, Zingg JM \& Azzi A (2000) Vitamin E reduces the uptake of oxidized LDL by inhibiting CD36 scavenger receptor expression in cultured aortic smooth muscle cells. Circulation 102, 82-87.

Rimbach G, Saliou C, Canali R \& Virgili F (2001) Interaction between cultured endothelial cells and macrophages: in vitro model for studying flavonoids in redox-dependent gene expression. Methods in Enzymology 335, 238-242.

Rimbach G, Valacchi G, Canali R \& Virgili F (2000) Macrophages stimulated with IFN-gamma activate NF-kB and induce MCP-1 gene expression in primary human endothelial cells. Molecular and Cell Biology Research Communications 3, 238-242.

Rubanyi GM (1993) The role of endothelium in cardiovascular homeostasis and diseases. Journal of Cardiovascular Pharmacology 22, 1-14.

Saliou C, Valacchi G \& Rimbach G (2001) Assessing bioflavonoids as regulators of NF-kB acitivity and gene expression in mammalian cells. Methods in Enzymology 335, 380-387.

Schwenke DC \& Behr SR (1998) Vitamin E combined with selenium inhibits atherosclerosis in hypercholesterolemic rabbits independently of effects on plasma cholesterol concentrations. Circulation Research 83, 366-377.

Serbinova E, Kagan V, Han D \& Packer L (1991) Free radical recycling and intramembrane mobility in the antioxidant properties of alpha-tocopherol and alpha-tocotrienol. Free Radicals in Biology and Medicine 10, 263-275.

Stewart-Lee AL, Forster LA, Nouroz-Zadeh J, Ferns GAA \& Änggård EE (1994) Vitamin E protects against impairment of endothelium-mediated relaxations in cholesterol-fed rabbits. Arteriosclerosis and Thrombosis 14, 494-499.

Stocker A, Zimmer S, Spycher SE \& Azzi A (1999) Identification of a novel cytosolic tocopherol-binding protein: structure, specificity, and tissue distribution. IUBMB Life 48, 49-55.

Stroes ES, Koomans HA, de Bruin TW \& Rabelink TJ (1995) Vascular function in the forearm of hypercholesterolaemic patients off and on lipid-lowering medication. Lancet 346, 467-471.

Suzuki YJ \& Packer L (1993) Inhibition of NF-kappa B activation by vitamin E derivatives. Biochemical and Biophysical Research Communications 193, 277-283. 
Suzuki YJ, Tsuchiya M, Wassall SR, Choo YM, Govil G, Kagan VE \& Packer L (1993) Structural and dynamic membrane properties of alpha-tocopherol and alpha-tocotrienol: implication to the molecular mechanism of their antioxidant potency. Biochemistry 32, 10692-10699.

Tada H, Ishii H \& Isogai S (1997) Protective effect of D-alphatocopherol on the function of human mesangial cells exposed to high glucose concentrations. Metabolism 46, 779-784.

Terasawa Y, Ladha Z, Leonard SW, Morrow JD, Newland D, Sanan D, Packer L, Traber MG \& Farese RV Jr (2000) Increased atherosclerosis in hyperlipidemic mice deficient in alphatocopherol transfer protein and vitamin E. Proceedings of the National Academy of Sciences USA 97, 13830-13834.

Thiery J, Teupser D, Walli AK, Ivandic B, Nebendahl K, Stein O, Stein Y \& Seidel D (1996) Study of causes underlying the low atherosclerotic response to dietary hypercholesterolemia in a selected strain of rabbits. Atherosclerosis 121, 63-73.

Traber MG \& Kayden HJ (1989) Alpha-tocopherol as compared with gamma-tocopherol is preferentially secreted in human lipoproteins. Annals of the New York Academy of Sciences 570, 95-108.

Traber MG, Sokol RJ, Burton GW, Ingold KU, Papas AM, Huffaker JE \& Kayden HJ (1990) Impaired ability of patients with familial isolated vitamin $\mathrm{E}$ deficiency to incorporate alphatocopherol into lipoproteins secreted by the liver. Journal of Clinical Investigation 85, 397-407.

Watanabe CM, Wolffram S, Ader P, Rimbach G, Packer L, Maguire JJ, Schultz PG, \& Gohil K (2001) The in vivo neuromodulatory effects of the herbal medicine ginkgo biloba. Proceedings of the National Academy of Sciences USA 98, 6577-6580.

Welty FK, Lichtenstein AH, Barrett PH, Jenner JL, Dolnikowski GG \& Schaefer EJ (2000) Effects of ApoE genotype on ApoB-48 and ApoB-100 kinetics with stable isotopes in humans. Arteriosclerosis Thrombosis and Vascular Biology 20, 1807-1810.
Williams RJ, Motteram JM, Sharp CH \& Gallagher PJ (1992) Dietary vitamin $\mathrm{E}$ and the attenuation of early lesion development in modified Watanabe rabbits. Atherosclerosis 94, 153-159.

Williams SB, Cusco JA, Roddy MA, Johnstone MT \& Creager MA (1996) Impaired nitric oxide-mediated vasodilation in patients with non-insulin-dependent diabetes mellitus. Journal of the American College of Cardiology 27, 567-574.

Wu D, Hayek MG \& Meydani S (2001) Vitamin E and macrophage cyclooxygenase regulation in the aged. Journal of Nutrition 131, 382S-388S.

Yamauchi J, Iwamoto T, Kida S, Masushige S, Yamada K \& Esashi $\mathrm{T}$ (2001) Tocopherol-associated protein is a ligand-dependent transcriptional activator. Biochemical and Biophysical Research Communications 285, 295-299.

Yan SD, Schmidt AM, Anderson GM, Zhang J, Brett J, Zou YS, Pinsky D \& Stern D (1994) Enhanced cellular oxidant stress by the interaction of advanced glycation end products with their receptors/binding proteins. Journal of Biological Chemistry 269, 9889-9897.

Yoshida N, Manabe H, Terasawa Y, Nishimura H, Enjo F, Nishino $H$ \& Yoshikawa T (2000) Inhibitory effects of vitamin $E$ on endothelial-dependent adhesive interactions with leukocytes induced by oxidized low density lipoprotein. Biofactors 13, 279-288.

Zapolska-Downar D, Zapolski-Downar A, Markiewski M, Ciechanowicz A, Kaczmarczyk M \& Naruszewicz M (2000) Selective inhibition by alpha-tocopherol of vascular cell adhesion molecule-1 expression in human vascular endothelial cells. Biochemical and Biophysical Research Communications 274, 609-615.

Zimmer S, Stocker A, Sarbolouki MN, Spycher SE, Sassoon J \& Azzi A (2000) A novel human tocopherol-associated protein: cloning, in vitro expression, and characterization. Journal of Biological Chemistry 275, 25672-25680. 